SHS Web of Conferences 2, 00036 (2012)

DOI: $10.1051 /$ shsconf $/ 20120200036$

(C) Owned by the authors, published by EDP Sciences, 2012

\title{
Patient groups in art therapies: A case study of the health care field in Latvia
}

\author{
A. Upmale ${ }^{1}$, K. Martinsone ${ }^{2}$, I. Vaverniece ${ }^{3}$ and K. Vende ${ }^{4}$ \\ ${ }^{1}$ VSIA BKUS children hospital "Gailezers", Latvia \\ ${ }^{2}$ Rïga Stradinš University, Latvia \\ ${ }^{3}$ Arts Therapies Centre, Latvia \\ 4 Society "Dzintarkrasta service", social care centre", Latvia
}

\begin{abstract}
The aim of the paper is to introduce the reader with an example of the arts therapies work in a children hospital in Latvia in order to describe art therapies work similarities and differences in three different specializations. Comparison will take place of patient groups in the work of art therapists in each specialization (art therapy, dance movement therapy and music therapy). The question of the research is: with which patient groups' a specialist from a particular arts therapies specialization has worked within a year in VSIA BKUS children hospital "Gailezers" during the time period from 05.2009 to 05.2010?The results were gained by comparing patient groups at the age from 2,5 to 17 years in the children hospital and they showed that the art therapists and dance movement therapist most frequently were working with patients who have behaviour and emotional disorders. However music therapists are working more frequently with patients who have mental retardation.
\end{abstract}

Key words: arts therapies, patient groups, health care, children hospital

A new integrative health care facilitating and maintenance possibility - arts therapies - has developed in the second quarter of the $20^{\text {th }}$ century. In some countries arts therapies have been applied in psychiatric and somatic clinics in order to facilitate patient's rehabilitation already since $40-50$-ies of the $20^{\text {th }}$ century.

Arts therapies in Latvia have become a field of the health care since 2005 when professional standards were recognized by the Latvian Ministry of Education (Mārtinsone K., 2011). Art therapist is a heath care person, who has got a second level of the professional higher education (master degree) in the health care and a professional qualification in one of the arts specialties (art, dance movement, drama or music). The arts therapies and the professional work of art therapists in Latvia have been recognized in the normative documentation and in the documents of professional associations. Arts therapies have been approved as medical technologies in 2010 as well. So in order to work as an art therapist and to offer professional services in the particular arts therapies specialisation one must gain appropriate education and a professional qualification.

Nowadays the question about the patient groups the art therapist from particular arts therapies specialisations work with is widely actualized in many different countries (Coats, 2004; Karkou, Sanderson, 2006; Karkou, 2010). Art therapists in Latvia work in health care, social care and education fields with patients who gave got somatic, psychic disorders and psychological difficulties. Often they work in a multiprofessional team.

The aim of this research is to look for the patient groups in different arts therapies specialisations in Latvian by describing one of the working examples - art therapists' work at the VSIA BKUS Children hospital "Gailyezers". Here similarities and differences of arts therapies' characteristics in different specializations (art therapy, dance and movement therapy and music therapy) have been emphasized. The comparison has been implemented by the analyses of the different client groups in

This is an Open Access article distributed under the terms of the Creative Commons Attribution License 2.0, which permits unrestricted use, distribution, and reproduction in any medium, provided the original work is properly cited. 


\section{SHS Web of Conferences}

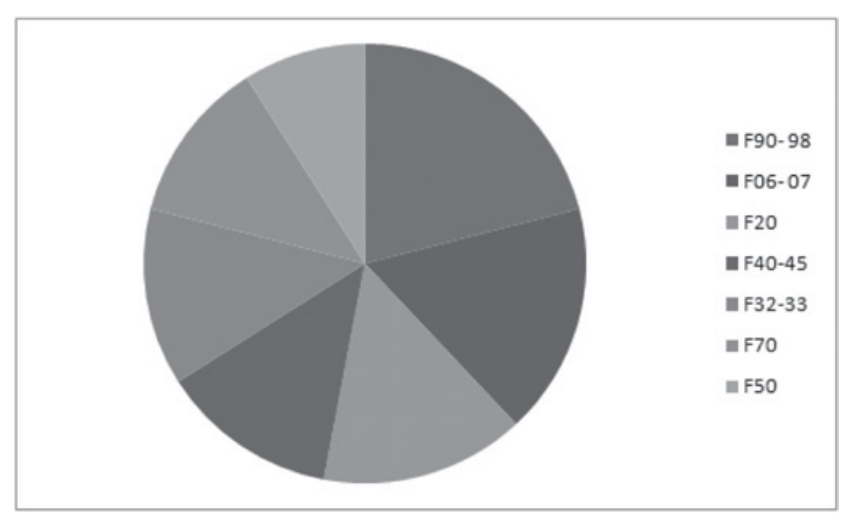

Figure 1. Patient groups in the AT at the VSIA BKUS children hospital "Gailgezers".

each specialization. The question of the research is as follows: with which patients groups' art therapists from different arts therapies specializations have worked within a year in VSIA BKUS children hospital “Gailezers” from 05.2009 to 05.2010.

\section{Method}

\section{Participants}

Patients of the VSIA BKUS children hospital "Gaiļezers" in the age from 2, 5 to 17 years, who have been hospitalised in the hospital from 05.2009 to 05.2010.

\section{Method}

The method of the research is document analyzes.

\section{Procedure}

Patients' medical cards are analyzed in which the consultations of doctors and other health care professionals (including all specialization arts therapists) are stated. Only those patients' medical cards are included in the research who are referred to any of arts therapies by their attending psychiatrist. The diagnoses are used in the medical card in order to describe and state patients difficulties, according to VSIA BKUS children hospital "Gailsezers” rehabilitation service policy.

\section{Results}

Results will be reviewed according the each arts therapies specialisation.

The total number of the art therapy (AT further on) patients during 12 months is 130. Average number of sessions in an inpatient unit per one patient is 4 sessions, age of the patients are from 5 to 17 years. Most common diagnoses and patient groups in the AT - behavioural and emotional disorders with onset usually occurring in childhood and adolescence 21\% (F90-F98); organic personality and behaviour disorders 17\% (F06-F07); schizophrenia 16\% (F20); neurotic stress-related somatoform disorders 15\% (F40-F45); depressive disorders 13\% (F32-F33).

The total amount of patients who participated the dance movement therapy (further on DMT) is 192 (see Figure 2). Average session number for one patient -4 sessions, age of the patients from 2,5 to 17 years. Most common patient diagnoses and patient groups in the DMT - behavioural and emotional disorders with onset usually occurring in the childhood and adolescence 27\% (F90-F98); mental 
Int. Conf. SOCIETY. HEALTH. WELFARE; Congr. of Rehabilitation Doctors of Latvia

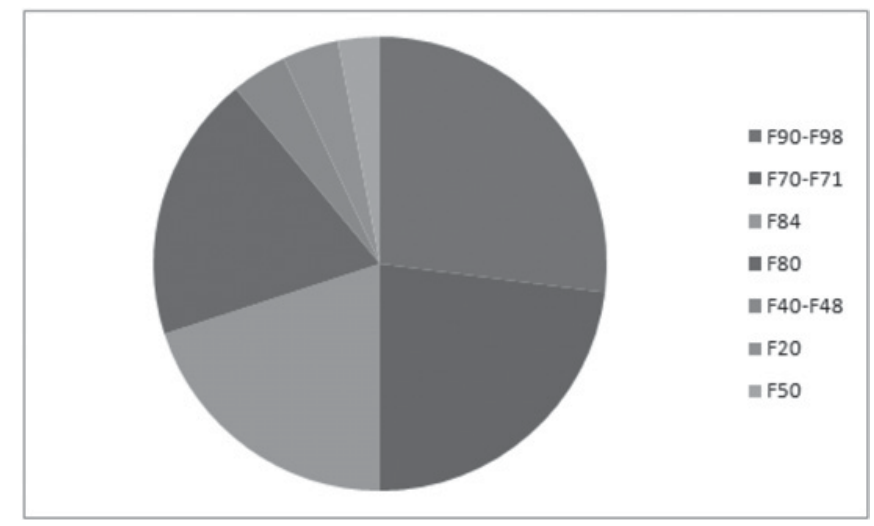

Figure 2. Patient groups in the DMT at the VSIA BKUS children hospital "Gailgezers".

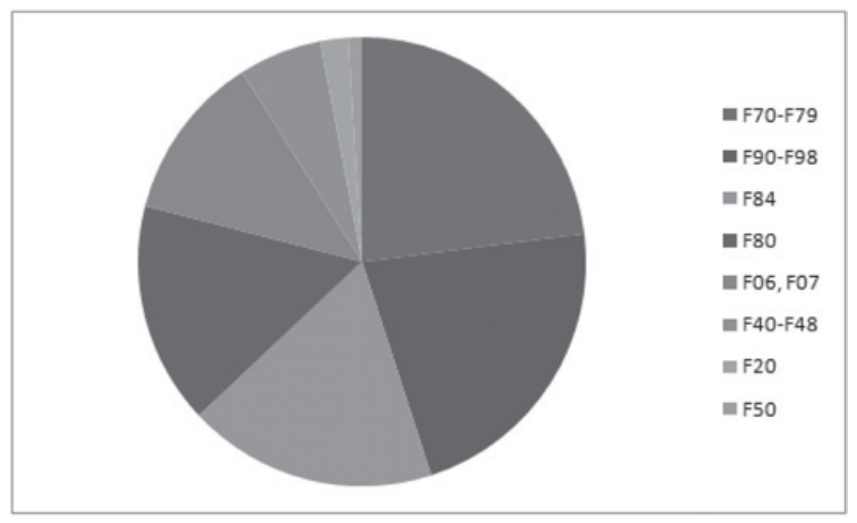

Figure 3. Patient groups in the MT at the VSIA BKUS children hospital "Gailyezers".

retardation 23\% (F70-F71); pervasive developmental disorders 20\% (F84); specific developmental disorders of speech and language 19\% (F80).

Total amount of patients in the music therapy (further on MT) is 251 (see figure Nr.3). Average number of sessions for one patient in the MT -4 sessions, age of the patients from 2,5 to 17 years old. Patient' diagnosis and patient groups - mental retardation 23\% (F70-F79); behavioural and emotional disorders with onset usually occurring in the childhood and adolescence 22\% (F90-F98); pervasive developmental disorders 18\% (F84); specific developmental disorders of speech and language 16\% (F80).

\section{Discussion}

To discuss the results of the particular survey it is relevant to do a small retrospection about the establishment of arts therapies as a profession in Latvia. Historically as an influence to the development of arts therapies in Latvia the Russian and German tradition should be pointed out as prior (Mārtinsone, 2011). However since 2005 when the profession of arts therapies has been established with clear requirements regarding the professional membership as well for the education of arts therapies association members, their further education, supervision, certification and so on, based on the GB tradition, the "British model" has been adapted to the situation in Latvia (Karkou, Martinsone, Nazarova, Vaverniece, 2011). 


\section{SHS Web of Conferences}

Basic to the connection between Latvian and the GB, The Great Britain's experience and data of a broad national research, done by Vicky Karkou and Patricia Sanderson, have been implemented for the discussion of the results (Karkou, Sanderson, 2006). The Latvia' and Great Britain's (further on GB) data overview is considered as a comparison of tendencies in both countries as Karkou and Sanderson have gathered the information about the patient groups art therapists are working with in the GB as part of a wider research. It is necessary to note that the patient group division in the GB research is related to a model which is called by authors as a model from pedagogy. It means also avoidance to use medical terminology in that research (Karkou, Sanderson, 2006). When they look to the patients they do not use particular diagnoses and divide them into the groups according to the problems such as: emotional and behaviour difficulties, learning difficulties, physical/medical or sensor disorders and so on. However in Latvia's research the International Classification of Mental and Health Disorders (ICD 10) has been used, according to organisational policy.

One of the tendencies in Latvia is that DMT and MT are working more with patients to which a nonverbal communication. It is stated in the literature that for this patient group nonverbal communication is frequently the only one mean of self expression and communication - delivery of information and emotional attitudes, (Mac Donald, 2006; Sherbourne, 2001). AT in comparison comparatively often work with patients to which verbal communication is used in order to talk over the creative process as well as for making connections between the creative process and/ or its result and also the language expresses the content of the ones' inner world, experience and relationship system.

As it is shown above in the results the most common diagnoses and patient groups in the AT are behavioural and emotional disorders, and also according the Karkou and Sanderson survey - the patient difficulties AT work with are the same in the GB. Karkou and Sanderson suggest that these findings might reflect the pioneering work of Adamson and Champernowne who worked with people with mental issues at the beginning of the AT development (Karkou, Sanderson, 2006; 159).

According to the VSIA BKUS children hospital "Gailsezers" research data the main patient group for the MT are patients with mental retardation. The GB data of Karkou and Sanderson show that also a half of the British MT are working with this patient group while in other arts therapies specializations the work with this patient group takes considerably less place. British authors explain those results with the MT development in which Alvin has given a significant contribution with her work with children who had autisms by defining professional basic approaches, including value of improvisation in the therapeutic process. Also Nordoff and Robbins who worked with this patient group gave a great impact to Mt professional development (Karkou, Sanderson, 2006; 120). MT work in Latvia is running according to the British example and above mentioned professionals. Historical significance of establishing these traditions is due to Dr. Rer. Med. Reineram Haus and Vestische Kinder-und Jugendklinik Datteln, Universität Witten, Herdecke (Mārtisone, 2011; 61).

Following arts therapists work with different patient groups worldwide the historical significance of professional development can be highlighted (Vāverniece, 2011). Although according to the VSIA BKUS Children hospital "Gailezers" data, exactly this patients is the biggest in the MT and DMT, those data about Latvia does not show such a notable difference in amount of patients group with emotional and behaviour disorders, where professional development and influence of pedagogy field is appears.

Similarly to AT, also DMT field the main patient group in both countries is people with emotional and behaviour disorders. Karkou and Sanderson pointed to the DMT pioneer', American Chase impact on this profession development as she worked with people suffering form chronic mental health problems. Authors mention also that the DMT training and placements mostly take place in these settings. British research, mainly qualitative, indicate that DMT is successful with adolescents who have behaviour difficulties or disorders (Capello, 2009; Karkou, Sanderson, 2006), victims of sexual abuse, people suffering from demence, brain injury and eating disorders. The difference between both countries is in fact that in GB DMt are mostly working in the educational field, accordingly not so much in the health care. 
Int. Conf. SOCIETY. HEALTH. WELFARE; Congr. of Rehabilitation Doctors of Latvia

\section{Conclusions}

Authors of the this paper came to conclusions by comparing three arts therapies specializations and their patient groups during the 1 year period at the VSIA BKUS children hospital "Gailezers" that the AT most frequently have been working with patients who are suffering from emotional and behaviour disorders. Unlike DMT and MT, AT are more often working with patients diagnosed with schizophrenia, neurotic stress-related somatoform disorders and depressive disorders.

The patient groups for the DMT and MT specialisation are more similar. DMT and MT more frequently are working with patients who are mentally retarded and have emotional and behaviour disorders. Unlike AT, DMT and MT also work more with patients suffering from pervasive developmental disorders and specific developmental disorders of speech and language.

Some similarities arouse by comparing patient groups in Latvia's VSIA BKUS Children hospital "Gailezers" and the Great Britain's research. Both Latvia's and The GB art therapists in all three specializations more commonly work with patients who have emotional and behaviour disorders or difficulties, mental retardation or learning difficulties.

It is significant to continue and expand started research by including various patient groups from all art therapy specializations and from the health care, educational and social fields.

\section{References}

[1] Capello, P. (2009) BASICS: An Intra/Interactional Model of DMT with the Adult Psychiatric Patient. In Chaiklin, S. \& Wengrower, H. (eds.) The Art and Science of Dance/Movement Therapy: Life is Dance. London: Routledge.

[2] Coats, E. (ed.) (2004) Creative Arts and Humanities in Healthcare: Swallows to Other Continents: A strategic paper prepared by a collaborative inquiry group. London: Nuffield Trust.

[3] Karkou, V. (2005) Dance movement therapy in the community: group work with people with enduring mental health difficulties In Levy, F. (ed.). Dance movement therapy: a healing art. London: Routledge.

[4] Karkou, V. (ed.) (2009) Arts Therapies in Schools: Research and Practice. London: Jessica Kingsley Publishers.

[5] Karkou, V. (2010) Arts Therapies. Art, Dance Movement, Drama and Music Therapy. Hitting the HEAT Targets. http://www.badth.org.uk/downloads/information/ ArtsTherapiesReportHittingtheHEATTargets.pdf

[6] Karkou, V., Martinsone, K., Nazarova, N., Vaverniece, I. (2010) Art therapy in the postmodern world: Findings from a comparative study across the UK, Russia and Latvia. In The Arts in Psychotherapy. (in Press). Available online 24 Dec. 2010.

[7] MacDonald, J. (2006) Dance? Of cource I can! Dance Movement therapy for people with leartning difficulties. In Payne, H. (ed.) Dance movement therapy: theory and practise. London: Routledge.

[8] Mārtinsone, K. (ed.) (2011) Mākslu terapija. Rīga: RaKa.

[9] Mārtinsone, K. (2011) Mākslu terapijas izveide un attīstība Latvijā. Martinsone, K. (ed.) Mākslu terapija. Rīga: Raka.

[10] Mārtinsone, K., Mihailova, S., Mihailovs, I.J., Majore-Dūšele, I., Paipere, M. (2008) Mākslu terapijas un tās attīstības konteksti (integratīvi eklektiskā pieeja Latvijā). Rīga: RSU.

[11] Payne, H. (2006) Shut in, shut out: Dance movement therapy with children and adolescents. In Payne, H. (ed.) Dance movement therapy: theory and practise. London: Routledge.

[12] Sherbourne, V. (2001) Developmental Movement for Children: Mainstream, Special needs and preschool. Second edition. London: Worth Publishing.

[13] Vāverniece, I. (2011) Mākslu terapija: veselības aprūpes profesijas izveide un attīstība. Mārtinsone, K. (ed.) Mākslu terapija. Rīga: Raka. 